Lisbon - Malacca Port Cities Twin Conferences 2019 / 2020

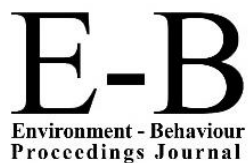

AicQoL2020Malacca

ASLI (Annual Serial Landmark International) Conferences on QoL2020

https://www.amerabra.org; https://fspu.uitm.edu.my/cebs; https://www.emasemasresources.com/

8th AMER International Conference on Quality of Life

Mahkota Hotel Melaka, Malacca, Malaysia, 18-19 Mar 2020

(Due to the Covid-19 lockdown, paper virtually presented on 25 Mar 2020)

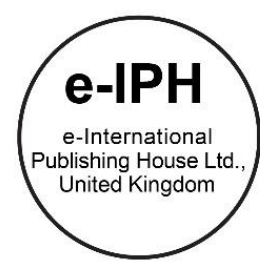

\title{
Democratic Street: An application of Space Syntax in testing the spatial justice among women pedestrian
}

\author{
Nurul Shakila Khalid, Na'asah Nasrudin, Yusfida Ayu Abdullah, Ishak Che Abdullah \\ Centre of Studies for Town and Regional Planning, Faculty of Architecture, Planning and Surveying, \\ Universiti Teknologi MARA Puncak Alam Campus, 42300 Selangor, Malaysia \\ shakilakhalid@uitm.edu.my,naasa717@uitm.edu.my, yusfida@uitm.edu.my, ishak2162@uitm.edu.my \\ Tel: +6032586248
}

\begin{abstract}
This research aims to examine the spatial dominance with the relationship between the spatial configuration of streets network and public life among women through the application of Space Syntax. Axial lines are measures to address the effect of layout pattern on movement and public life by applying global and local integration. The result indicated that there is a correlation between spatial configurative analyses and women present in the streets; more integrated and localised streets attract more women pedestrians, but short length stays. The research is relevant to spatial design interventions and design policymaking to improve equal access to public spaces.
\end{abstract}

Keywords: Democratic street; spatial sonfiguration; space syntax; women

eISSN: 2398-4287 @ 2020. The Authors. Published for AMER ABRA cE-Bs by e-International Publishing House, Ltd., UK. This is an open-access article under the CC BYNC-ND license (http://creativecommons.org/licenses/by-nc-nd/4.0/). Peer-review under responsibility of AMER (Association of Malaysian Environment-Behaviour Researchers), ABRA (Association of Behavioural Researchers on Asians) and cE-Bs (Centre for Environment-Behaviour Studies), Faculty of Architecture, Planning \& Surveying, Universiti Teknologi MARA, Malaysia.

DOI: https://doi.org/10.21834/e-bpj.v5i13.1967

\subsection{Introduction}

The aim of creating democratic streets in walkable is to invite people on the street or pedestrianisation (Francis, 2016). Goodsell (2003) claims that in the transportation perspectives, the democratic street design is a subset of the walkable environment, those intended to support pedestrians and operated to enable safe access for all users. Democratic streets help achieve equity objectives by improving mobility and accessibility option for non-drivers. If the non-driving users are overrepresented by the poor, elderly, gender imbalance, and people with disabilities, then designing streets that give non-drivers a fair share of street space thus will make streets democratic (Zavestoki and Agymen, 2014; Beebeejaun, 2017).

Few studies examine the movement and activities that occur in urban public spaces related to the gender composition space (Arjmand, 2016; Beebeejaun, 2017; Francis, 2016; Khalili et al., 2015; and Souza et al., 2018). The current study addresses these limitations and fills a gap by counting women and men on streets that differ in space use. For the sake of diversity and spatial justice, it is essential that women feel safe, welcoming, and comfortable on urban streets as these areas provide great opportunities to engage in economic, physical, and social activity. Ever, street avoidance, safety or uneasiness, especially for women, become a concern especially female employment has increased in past decades thus show that women have had a strong presence in public spaces and make them be a part of urban life (Mehta, 2007; Tandogan and Ilhan, 2016; Beebeejaun, 2017). Indeed, women have reported that they are likely to experience public hassles and incivilities and be in the streets or public spaces. However, several factors such as safety, crime, rising of car-dependent lead to fewer women presence in the public space (Khalili et al., 2015; Souza et al., 2018). These studies have found the similar findings that assess street use by gender have identified women are often not quite half the users, as eloquently quoted by

eISSN: 2398-4287 (C 2019. The Authors. Published for AMER ABRA cE-Bs by e-International Publishing House, Ltd., UK. This is an open-access article under the CC BYNC-ND license (http://creativecommons.org/licenses/by-nc-nd/4.0/). Peer-review under responsibility of AMER (Association of Malaysian Environment-Behaviour Researchers), ABRA (Association of Behavioural Researchers on Asians) and cE-Bs (Centre for Environment-Behaviour Studies), Faculty of Architecture, Planning \& Surveying, Universiti Teknologi MARA, Malaysia

DOI: https://doi.org/10.21834/e-bpj.v5i13.1967 
Souza et al., (2018). One of the factors contribute to the less absence among women in urban space is the perception of safety; poorly maintained buildings, homeless, strangers, crime hotspot, poor streetscape, gloomy business activities, and internal and street exterior (Tandogan and Ilhan, 2016; Arjmand, 2016). Previous feminist geography has examined the complex ways that gender articulated through spatial practices in urban spaces. One of the spatial methods, movement across space, reflects the interrelation between available resources and social identities to construct gender identities (Beebeejaun, 2017). Given this emphasis, the specific research question has been set up; (i) what type of activities among women pedestrians support the public life in urban public spaces, and (ii) to what extent spatial configuration measures the success of street as a public space for all. This study indeed contributes to the literature by offering insightful knowledge of the roles of public spaces with the effects on an everyday activity and social interaction by analysing the spatial configuration of street networks.

\subsection{Literature Review}

\subsection{Public Space and Public Life}

The other side of the coin when dealing with space is often forgetting. Public life continually changes in a day, week or month and over the years. Besides, design, gender, age, socio-economic backgrounds, culture and other factors determine how people use or do not use public space. In this context, public space can be understood as streets, buildings, squares, alleys, corridors - everything that can be considered as part of the built environment. While public life should also be understood in the broader perspective as everything takes place between buildings, to and from grocery shops, walking, seated, standing, or hanging out (Gehl and Svarre, 2013). It is the complex life that unfolds in public space.

In Paris, a stranger feels at home because they can inhabit the city the way they live inside their own four walls. Just as one makes an apartment comfortable by living in it, and not merely using it for sleeping, eating and working, one becomes comfortable in the city by strolling through it without any purpose, stopping off at one cafe and shops that line the streets and past which the life of the city, the flow of pedestrians, moves along (Cheshmehzangi and Heat, 2012). The squares of Rome, the streets of Venice, Europe and North America, main streets, ordinary streets and sidewalks - these are traditional open-air public spaces, very well-known through history and yet still around. Handed over from previous generations with their memories of days and life past, they are still, in varying degrees, as part of public life. In the pursuit of life's enjoyment, Italians make strolling as their daily ritual activity. The town will close its main thoroughfare to all motorised traffic - pioneers in pedestrianisation. Spain has its rambla and paseo, France its cours, allée and promenade, and Italy its corso. At all times, and long before people's actions and emotions exhibited against payment on the stage, the street itself has been the excellent world theatre, poetry readings, drama and comedy were presented by daily life as a life in the street in a century ago (Mehta and Bosson, 2010, Mehta, 2009; 2013 and Gehl and Svarre, 2013).
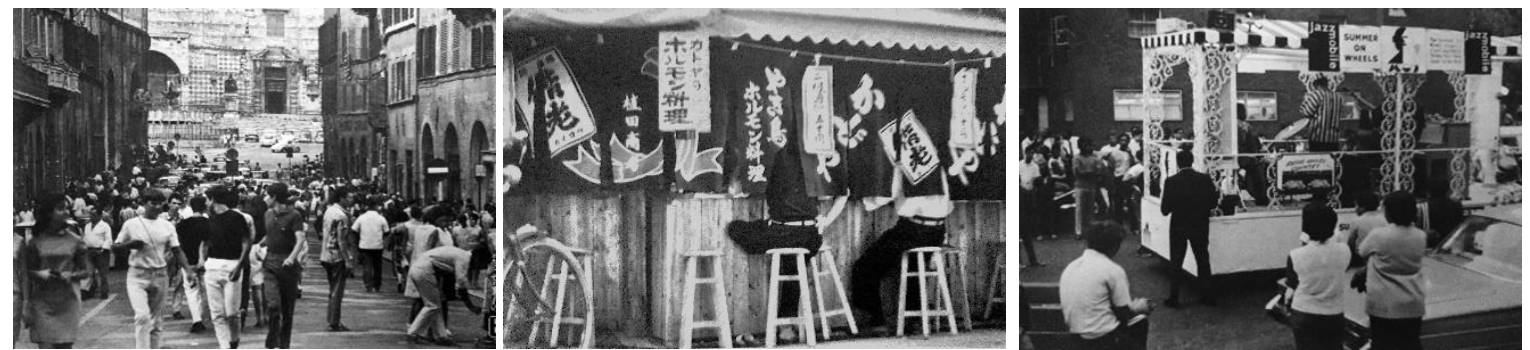

Fig. 1: Meeting people, watching what is going on, eating, seeing young and old, and being entertained by a street musician, ordinary daily street life or ever-changing human scene. These are the subtle, traditional joys related to life in public spaces.

(Source: Rudofsky, 1969)

\subsection{The Applications of Space Syntax in Testing the Street's Democracy}

Space Syntax is a set of theories that explain the relationship between a spatial pattern and the human behaviour developed by Bill Hillier and Julienne Hanson in 1970s. The method consists of calculating configurative spatial relationships in built environments involves measuring the accessibility of all parts of a network under consideration from each element. According to Hillier (2007), Space Syntax can be considered as an alternative model of space at the cognitive level and as a practical computational method for the urban patterns and structures analysis. The spatial configuration of a city plays a role as a projection of the social relations of its inhabitants (Hillier and Hanson, 1989). In additional, configurational descriptions and observational studies of cities have revealed that the spatial layout design includes the length, connectedness and position occupied by each route of movement within the gridded system will influence the density of human movement and activities that occurs along with (Crucitti et al., 2006; Hillier, 2007). This theory provides the understanding that integration is a powerful predictor of how "busy" or how "quiet" a street activity is likely to be.

The significance of spatial structures in affecting the pedestrian activities and movement has been addressed through the framework of configurational analysis of Space Syntax (Hillier et al., 1993). It has centre attention of urban researchers onto the importance of the relations between the public life and spatiality of the city (Crucitti et al., 2006 and Hillier, 2007). Since pedestrian accessibility occurs according to the fine grain of the environment as well as to its larger-scale structure, appropriately discriminating measures of street connectivity are critical for designing the street for accessibility and improve public life in public spaces. Several factors include spatial 
configuration, the attractions of co-presence, pathway infrastructures and pedestrian comfort are considered with the accessibility measures for more streets' democracy.

\subsection{Methodology}

\subsection{Background of Study Area}

Petaling Street and Kasturi Walk were performing the role of a pedestrian shopping street among locals and tourists. When one thinks of the colourful street and cultural street, Petaling Street come to mind before others. Petaling Street or also known as Chee Cheong Kai means Starch Factory Street in Cantonese, referring to its history as the centre for the production of tapioca flour back then. Petaling Street was established and active since the mid-19th century Petaling Street was paved with red tiles and covered with a dragon-like canopy that keeps out the sun. With a wet market in the early morning, Petaling Street is one of the most famous imitations of "branded" items, selling various traditional foods, vegetables, trade, and presenting the public life in Kuala Lumpur. While Kasturi Walk is a covered and open-air flea market set along Jalan Kasturi, a street along with Kuala Lumpur Central Market, a historical craft centre. There are over 20 wooden kiosks with coconut leaves (to enhance the feeling of being in a kampung), and food stalls sell traditional Malaysian foods.

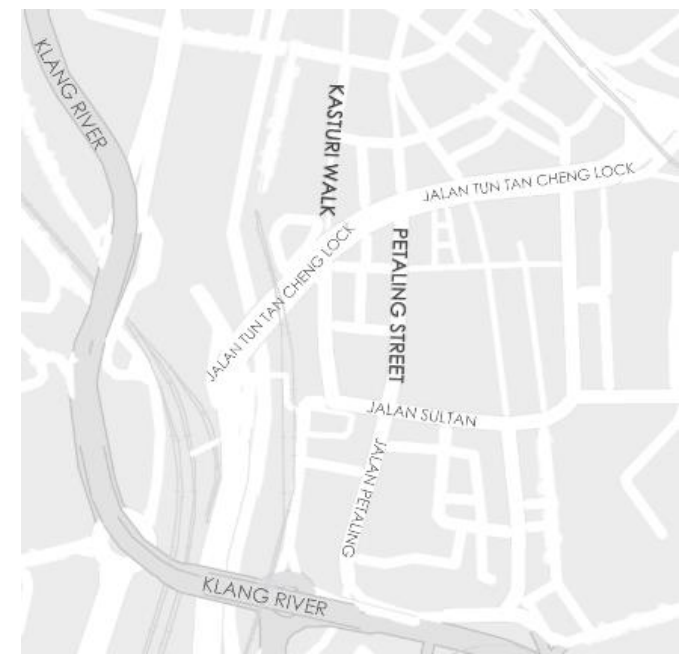

Fig. 2: Map of Petaling Street and Kasturi Walk, Kuala Lumpur.

\subsection{Qualitative Data collection}

This paper developed two basic key ideas; spatial configuration and gender-based accessibility. Spatial configuration plays a role in pedestrian accessibility (Hillier et al., 1993). The spatial configuration affects pedestrians when they have to make the decision what route they choose for their trips, or, encourage or discourage the route selection, which pedestrian can from arriving at the destinations. This scenario created a new niche in urban studies - the concept of the natural movement (Hillier et al., 1993). The natural movement various based on the distribution of configuration values in the axial map called integration (Hillier and Hanson, 1984).

Integration is an indicator of how easily one can reach a specific line of the axial map (Hillier et al., 1993; 2007). Integration measures the mean depth of every axial line. For the context of this research, the researcher employed two parameters in Space Syntax; local integration (micro-level) and global integration (the entire streets system). For the global integration of analysis, Space Syntax takes into consideration every possible relationship in the system - from anywhere to anywhere, whereas for the local integration analysis, only measure a particular local catchment area as three steps from the centreline. To achieve the research aim, axial analysis of two shopping streets was done within a $3 \mathrm{~km}$ radius using DepthMap. Figure 3 is the output of the axial line generated from the centreline of the street network in Kuala Lumpur.

To analyse the gender-based accessibility, the semi-structured observation was applied to measure individual and social stationary activities among women pedestrian such as talking, eating, shopping, taking a photo, walking, smoking, and social activities engaged in and the number of the pedestrian in Petaling Street and Kasturi Walk, Kuala Lumpur. Pedestrians communicating with each other or engaged in everyday activities indicated as a group. The observation was scheduled for typically busy daylight times spread out on weekdays and weekends (weekdays $8.00 \mathrm{am}$ to $8.30 \mathrm{am}, 1.00 \mathrm{pm}$ to $1.30 \mathrm{pm}$ and $5.00 \mathrm{pm}$ to $5.30 \mathrm{pm}$; weekends $11.00 \mathrm{am}$ to 11.30 $\mathrm{pm}$ and $5.00 \mathrm{pm}$ to $5.30 \mathrm{pm}$ ). The observations included (i) tracking number of people, (ii) duration of stay, and (iii) social activities engaged in the streets. Each observation was 15 minutes long to address the problem of observer fatigue. The literature studies of human activities and behaviour in public spaces showed that the duration of activities recorded in five-minute intervals. During the observation, the researcher acted as a participant-observer using the businesses and street space in the study areas. The researcher stands in the intersection in the centreline of the streets to record the social activities and count the number of pedestrians encountered using field notes. Besides, the research also applied photographs to record pedestrian behaviour patterns and to verify the observation data collected. 


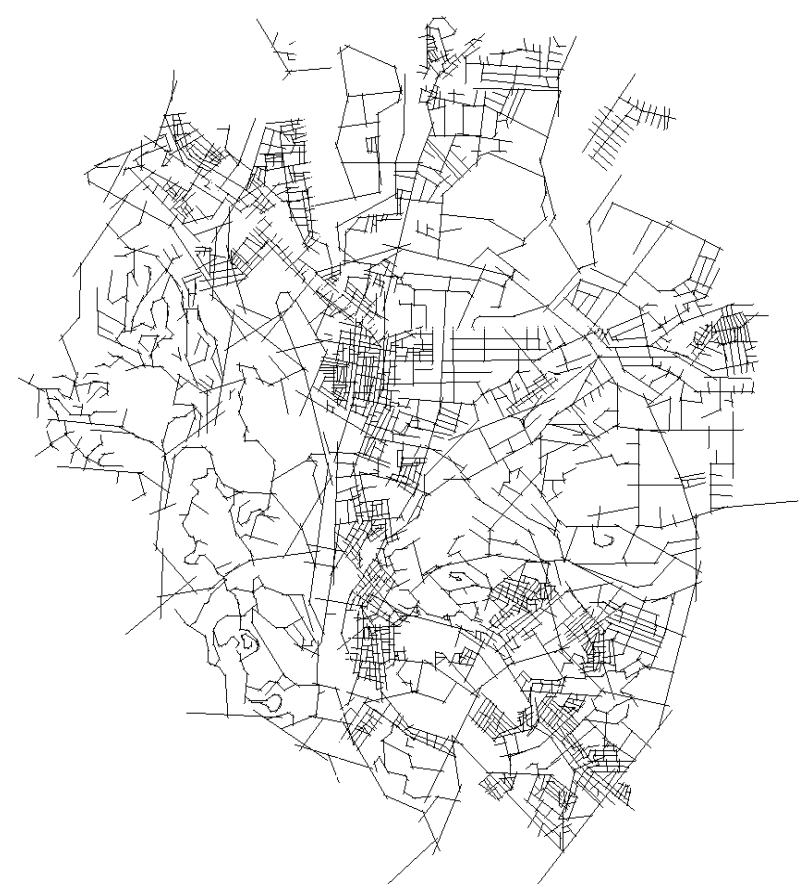

Fig. 3: The Axial map consists of 2,437 street segments of radius $3 \mathrm{~km}$ from the centreline of two streets (Petaling Street and Kasturi Walk) was audited in the DepthMap software.

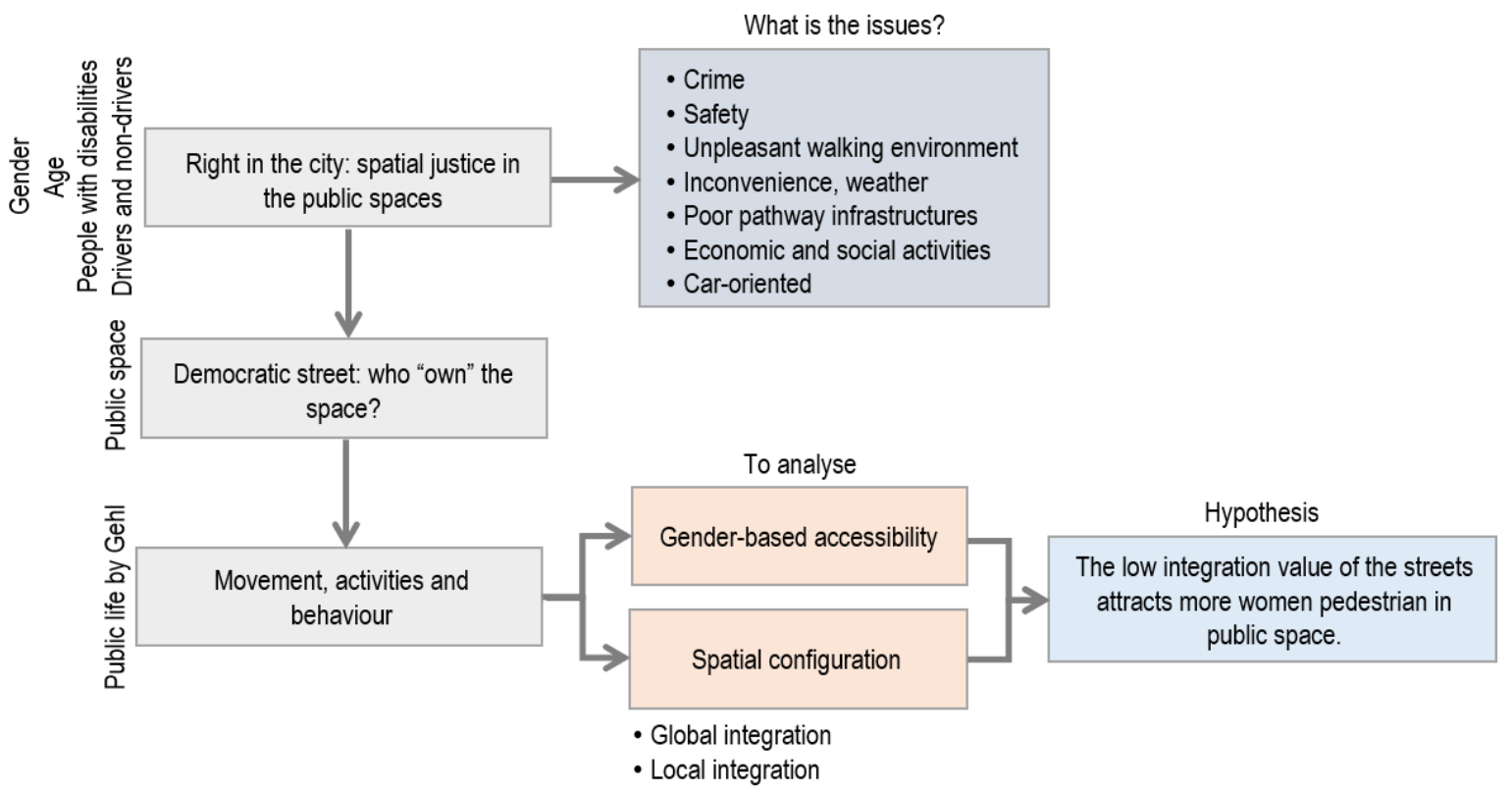

Fig. 4: Theoretical methodology.

(Source: Author)

\subsection{Findings}

\subsection{Analysis of Street Network Configuration}

Two analyses of the spatial layout pattern were conducted to address how to integrate and segregated the street networks for pedestrian trips (Hillier and Hanson, 1989). These readings go from neighbourhood scale to a city-scale as the main generator of patterns of movement. The first analysis was a global measurement $(\mathrm{Rn})$, which helped observe the relationship between each axis and all other axes, and to show the degree of integration. The secondary analysis was a local measurement (R3), which helped to identify the relationship of an axis with its connected axes (up to three steps away). Local integration is the default indicator for human movement, as Hillier stated that people tend to take paths that minimise trip length or maximise trip effectively. This called as natural movement 
whereas natural movement identifies natural human activities in the configuration of the street network. It means that urban designer could predict human activities in the street (read: space).

The spatial layout pattern of Kuala Lumpur within the $3 \mathrm{~km}$ radius shows that almost $80 \%$ of the area consists of a higher density of streets. This refers to the vehicular movement concentration in the central corridor of the transportation system. The concentration can be traced easily by looking at the street network, whereas the nucleus centre happened along the major road in the city centre (Hajrasouliha and Yin, 2015). For example, Jalan Tun Tan Cheng Lock, Jalan Tun HS Lee, Jalan Tun Perak and Jalan Hang Lekir dominated by vehicles and the loading and unloading activities that thus contributed to the traffic congestion. Notably, the layout patterns of Kuala Lumpur City Centre are semi-regular grid to very gridiron a non-uniform of distribution of land uses before the city begins to develop and extend. To measure the integrations, this paper refers to space/spatial as street and pedestrian paths of Kuala Lumpur. The pedestrian network includes all alleys, pathways, and pedestrian-only lane. Integration has analysed to measure the accessibility of the spatial layout pattern from the very grid with mainly linear through streets to the fewer grids and a deformed grid at a city scale. The integration values in Space Syntax represent global and local integration value of Petaling Streets and Kasturi Walk, as represents in Table 1. Amongst the streets, only Petaling Street and Kasturi Walk are the pedestrianisation for pedestrians to move, but with the multiple connectivities to each other streets.

Table 1. Syntactical values of Petaling Street and Kasturi Walk for pedestrian path networks compared to other streets

\begin{tabular}{l|c|c} 
& Global Integration (Rn) & Local Integration (R3) \\
\hline Petaling Street & $\mathbf{0 . 8 2 3}$ & $\mathbf{2 . 8 9 1}$ \\
Kasturi Walk & $\mathbf{0 . 8 9 8}$ & $\mathbf{2 . 6 9 7}$ \\
Jalan Benteng & 0.875 & 1.666 \\
Jalan Tun Tan Cheng Lock & 0.823 & 2.833 \\
Jalan Hang Lekir & 0.825 & 2.938 \\
Jalan Sultan & 0.735 & 2.799 \\
Leboh Pasar Besar & 0.986 & 2.636 \\
Jalan Tun Tan Siew Win & 0.911 & 2.469 \\
Jalan Tun Perak & 0.963 & 3.098 \\
Jalan Tun HS Lee & 1.114 & 3.255 \\
\hline
\end{tabular}

(Source: Author)

a)

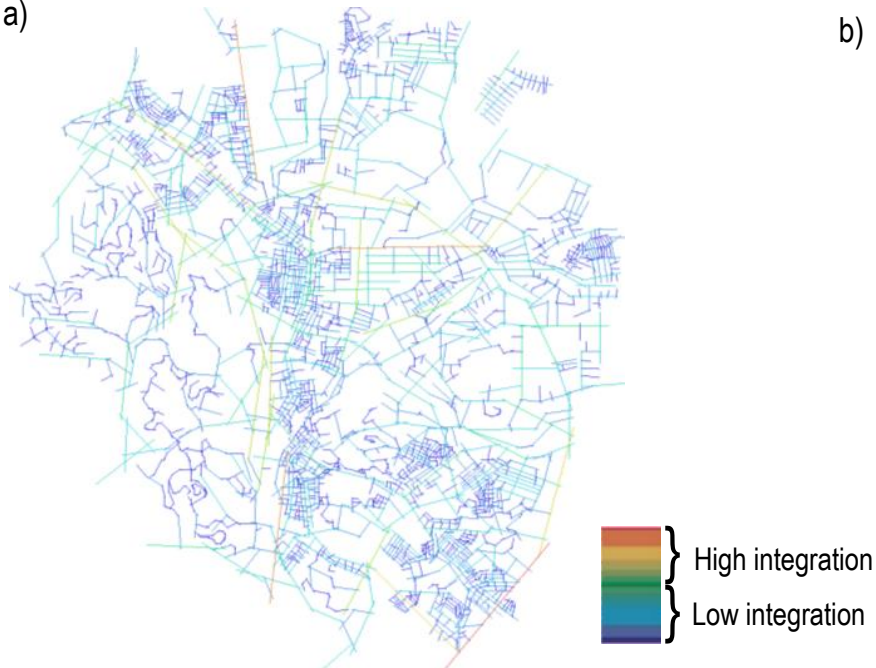

b)

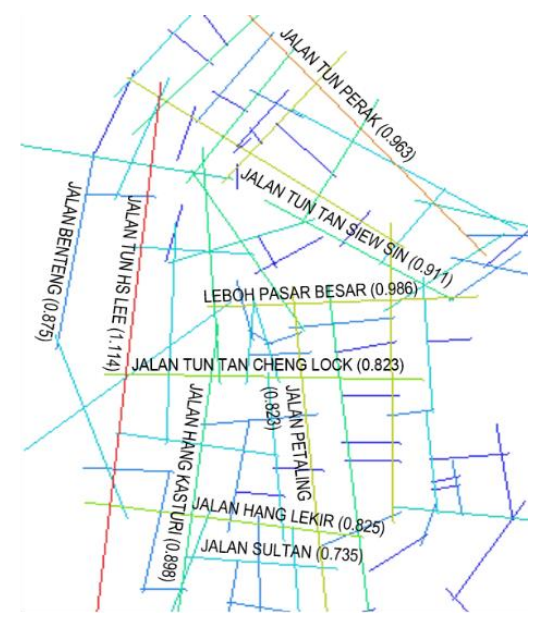

Fig. 5: (a) The global integration map shows higher values in the central area of Kuala Lumpur (b) Enlarged view of selected streets connected to Petaling Street and Kasturi Walk embedded in Kuala Lumpur. The result shows the more spatially integrated the street (represented by warmer colours; red to orange), the more pedestrian and car on the streets. In contrast, the more spatially segregated (cooler colours; green to blue) the streets are, the fewer pedestrian and vehicles on the streets.

The global integration values range 0 (lowest) to approximately 1 (highest). The highest global integration value indicates the axial lines can be accessed from all other axial lines. According to Table 1, Petaling Street and Kasturi Walk scored 0.823 and 0.898 for the global integration value. Both streets are approximately long 293m (Petaling Street) and 75m (Kasturi Walk) and can only be accessed by pedestrians. Kasturi Walk can be accessed by foot from Leboh Pasar Baru, Lebuh Pudu and Jalan Tun Sambathan to the Pasar Seni LRT and MRT stations. It can be observed that the spatial layout pattern in both areas are likely grid and buildings are located in a small cluster to encourage natural movement by foot.

The highest values of global integration are Jalan Tun HS Lee (1.114), Jalan Tun Perak (0.963), followed by Leboh Pasar Besar (0.986), and Jalan Tun Tan Siew Sin (0.911). These streets cater to more movements of vehicles and add to the higher street density. Jalan Tun HS Lee is amongst the highest value of global integration parallelly connected to roundabout Jalan Syed Putra. The second 
highest global integration value, Jalan Tun Perak specifically is a long-stretched street of $810 \mathrm{~m}$ with 23m of width that attached to Jalan Pudu and highly visual connected to other nearby streets such as Jalan Tunku Abdul Rahman. While Leboh Pasar Besar and Jalan Tun Tan Siew Sin also move the vehicles with the short length of the street. These streets are accessible to pedestrians, but due to the multiple connectivities to the transit stops, higher traffic volume, and thus make pedestrian avoid using the streets.

The results of local integration displayed a range of colours from the red lines as the more integrated streets through to the blue lines as less integrated streets. The local integration value represents in radius three. Figure 6 represents local integration measure that reflects the local scenario of a transportation network system.

The measures found that the most integrated locally is Jalan Tun HS Lee (3.255) and Jalan Tun Perak (3.098). Integration value for Petaling Street is 2.891, while the lowest integration value is Jalan Benteng (1.666). According to the Space Syntax principle, streets that had low integration values were safer and accessible by the pedestrian as it has proved that Jalan Benteng is fully accessible by pedestrian-only and known as riverfront along Sungai Klang and Sungai Gombak. Based on the observation in Petaling Street and Kasturi Walk, both streets are pedestrianised and locally high integrated. Pedestrian will easily be accessed both streets via other alternatives street as the layout pattern in mainly grid - short block and many options of routes.
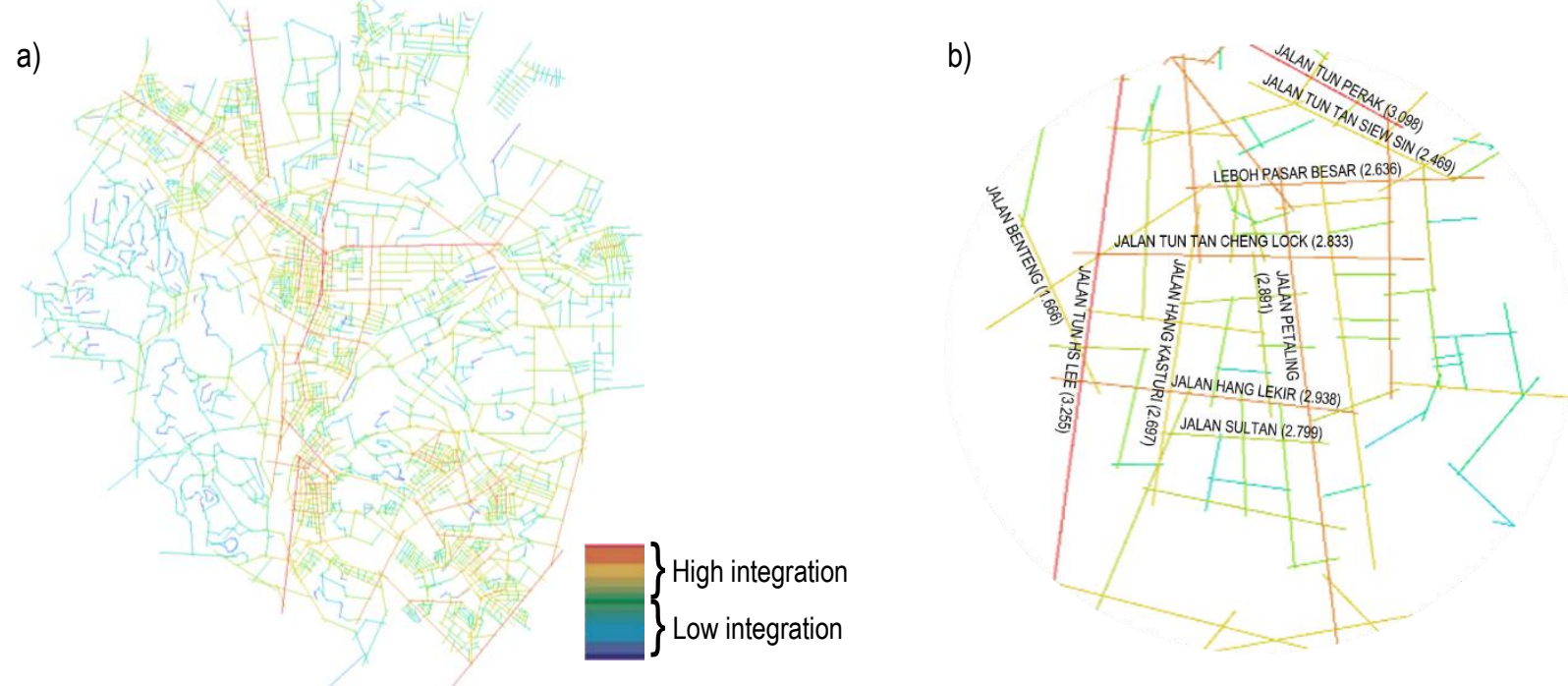

Fig. 6: (a) The local integration map indicates the average depth of a space to all other spaces within three depths in the network system (b) The local integration results show that the highest locally integrated street is Jalan Tun HS Lee followed by Jalan Tun Perak and Jalan Petaling which is accessible by vehicles.

\subsection{Analysis of Number of Women Pedestrian and the Activities}

The number of women pedestrians includes the local and tourists observed was between 100 to 400 women within 30 minutes in 7 days of observation. The number of women pedestrians found to increase after 10.00 am onwards, which is the wooden kiosks in Kasturi Walk (except the food stalls) open at 10.00 am while shops in Petaling Street open in the early morning at 7.00 am. From the observation, if they are locals, most of them are the workers, and less are strolling in weekday. Compare to the weekend, both streets occupied by the locals who come to do their shopping of the daily groceries and foods. Most women prefer to walk in a small group (at least two of them). But there are who choose to walk alone or with a man or with the families. If they walk alone, most of them are in a hurry and just passing through the street that they are on a trip to or from work. For the activities, the research purposely divides into two (2) types; individual and a group of pedestrian activities to compare how pedestrians may feel at ease and experience when walking in the public space alone or the group.

The number of a pedestrian in Petaling Street in weekday and weekend almost significance among local or tourist women pedestrian because Petaling Street offers a variety of goods include intimidating "branded" items. The observation found that there are two types of typical local pedestrians according to their age and purpose of visit. The typical local pedestrian is the older women shopping to buy daily groceries such as flowers, fruits, vegetables, and household items. The second typical local pedestrian is the easy-going pedestrian, who is the younger woman. They come to Petaling Street to taste the local Chinese food. According to the Table 2, bargain activities only happened among the tourists as the bargaining is the trick when shopping in Petaling Street and the tourist more attracts to shop the imitate branded items compare to the local people who only buy the daily goods and to meet the needs of food.

For the observed activity patterns in Kasturi Walk, most of the local women pedestrian (aged between the 20s to 50s) is walk alone and just passing to reach the LRT and MRT Pasar Seni, and to the nearby hotels, shops and offices. They usually walk while chatting while the number increased for standing during the weekends (see Table 3). The passer-by only stands in Kasturi Walk for less than 3 minutes to buy the food, especially in between 1.00 to $1.30 \mathrm{pm}$. They attempt to limit the use of outdoor activities in a public space because in a hurry and feel uncomfortable with the presence of the foreigners and leaves them insecure. While women pedestrians among the tourists walk at least two of them and in a group of families, however, they only stop in the shops in Kasturi Walk in less than 
3 minutes and they will continue to walk, or go inside the Central Market. Few people who are among the shop workers (mostly are foreign workers) stand or sit in front of the shops, having a conversation and lingering among them and dominant space.

Table 2. Types of women activities by individual and social per observation period (every 15 minutes in 3 slots of time) in Petaling Street

\begin{tabular}{|c|c|c|c|c|c|c|c|c|c|c|}
\hline & \multicolumn{7}{|c|}{ Individual } & \multicolumn{3}{|c|}{ Social } \\
\hline & 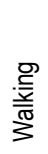 & $\begin{array}{l}\text { D } \\
\text { 吾 } \\
\text { 跑 }\end{array}$ & 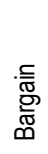 & 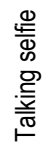 & $\begin{array}{l}\frac{0}{\overline{0}} \\
\frac{\overline{0}}{0} \\
\frac{c}{\omega}\end{array}$ & $\begin{array}{l}\text { 惡 } \\
\text { 焉 }\end{array}$ & $\begin{array}{l}\text { 产 } \\
\text { 产 } \\
\text { क }\end{array}$ & 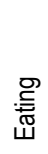 & $\begin{array}{l}\text { 焉 } \\
\text { 坖 } \\
\end{array}$ & 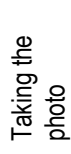 \\
\hline \multicolumn{11}{|c|}{ Weekdays } \\
\hline Day 1 & 61 & 27 & 17 & 6 & 22 & 28 & 3 & 35 & 15 & 3 \\
\hline Day 2 & 45 & 25 & 14 & 2 & 18 & 24 & 1 & 26 & 17 & 11 \\
\hline Day 3 & 49 & 29 & 23 & 10 & 37 & 17 & 2 & 22 & 21 & 14 \\
\hline Day 4 & 58 & 11 & 25 & 12 & 26 & 19 & 2 & 33 & 13 & 28 \\
\hline Day 5 & 37 & 18 & 27 & 9 & 25 & 15 & 2 & 20 & 19 & 24 \\
\hline \multicolumn{11}{|c|}{ Weekends } \\
\hline Day 1 & 69 & 62 & 30 & 5 & 37 & 25 & 0 & 41 & 23 & 25 \\
\hline Day 2 & 83 & 58 & 12 & 13 & 32 & 31 & 1 & 45 & 20 & 20 \\
\hline
\end{tabular}

Table 3. Types of women activities by individual and social and per observation period (every 15 minutes in 3 slots of time) in Kasturi Walk

\begin{tabular}{|c|c|c|c|c|c|c|c|c|c|c|}
\hline & \multicolumn{7}{|c|}{ Individual } & \multicolumn{3}{|c|}{ Social } \\
\hline & 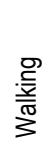 & $\begin{array}{l}\text { D } \\
\text { 吾 } \\
\text { 焉 }\end{array}$ & 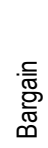 & 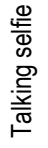 & $\begin{array}{l}\frac{\text { Dे }}{\overline{\frac{0}{0}}} \\
\text { क }\end{array}$ & $\begin{array}{l}\text { 罳 } \\
\text { 鹿 }\end{array}$ & $\begin{array}{l}\text { 胥 } \\
\text { है } \\
\text { क }\end{array}$ & 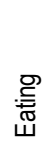 & 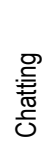 & 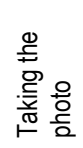 \\
\hline \multicolumn{11}{|c|}{ SWeekdays } \\
\hline Day 1 & 32 & 17 & 1 & 13 & 8 & 12 & 5 & 21 & 38 & 10 \\
\hline Day 2 & 39 & 8 & 4 & 10 & 5 & 18 & 3 & 17 & 26 & 18 \\
\hline Day 3 & 44 & 14 & 4 & 10 & 7 & 20 & 9 & 19 & 30 & 15 \\
\hline Day 4 & 56 & 7 & 3 & 21 & 11 & 25 & 4 & 16 & 17 & 7 \\
\hline Day 5 & 64 & 11 & 5 & 9 & 13 & 13 & 1 & 23 & 14 & 8 \\
\hline \multicolumn{11}{|c|}{ Weekends } \\
\hline Day 1 & 73 & 22 & 11 & 26 & 4 & 29 & 6 & 30 & 15 & 20 \\
\hline Day 2 & 81 & 24 & 9 & 22 & 9 & 27 & 3 & 28 & 20 & 25 \\
\hline
\end{tabular}

\subsection{Analysis of Duration of Stay and Proportion of Pedestrians}

The score given is according to the Vitality Index by calculating the number of people engaged in individual and social activities and duration of stay. A place would appear vitality in two scenarios; (i) a large number of people for short durations, or (ii) fewer people staying for longer durations. Each pedestrian observed in stationary social activity accounted for a one-unit score. The duration of stay was recorded under five categories, as shown in Table 4.

The observation result suggests that pedestrians in Petaling Street spend maximum time on the street. The highest number of pedestrians has a significant relationship with the duration of stay, especially the street, offers a variety of goods and businesses that meet the needs of local and tourist. It observed that women pedestrians engaged in social activities such as bargaining, shopping, and eating by spending 7 to more than 10 minutes. Besides, the street length is $293 \mathrm{~m}$ compared to Kasturi Walk, which is a $75 \mathrm{~m}$ long stretch, which gives ample time for a pedestrian to stroll and the walking environment is more convenient.

Observations in Kasturi Walk discovered on weekdays and weekend highlighted the difference in their duration of stay. On weekdays, pedestrian stayed there for a short length of less than 1 minute compare to in Petaling Street. Conversely, during the weekend, the length of stay increased from less than 1 minute to 5 minutes as the most significant number of pedestrians among locals and tourists enjoy the sightseeing, lingering, eating, shopping and appreciate the decorations in Kasturi Walk by taking the photo. Most of them spent more time (in less than 5 minutes) in food stalls compared to the souvenirs shops that sell the key chains, clothing, toys, handcraft, and accessories. They prefer to be in the Central Market due to the scorching hot weather the outside. The narrow space gives the feeling of inconvenience for pedestrians, especially for women who are strolling around with the infant in the stroller. Besides, there is no seating area or benches provided along Kasturi Walk except the seating for the food stalls. 
Table 4. Duration of stay of women pedestrian in Petaling Street and Kasturi Walk

\begin{tabular}{l|c|c}
\hline \multirow{2}{*}{ Duration of stay } & \multicolumn{2}{|c}{ Score } \\
\cline { 2 - 3 } & Petaling Street & Kasturi Walk \\
\hline $15 \mathrm{sec}$ to $<1 \mathrm{~min}$ & 5.0 & 1 \\
$1 \mathrm{~min}$ to $<3 \mathrm{~min}$ & 7.5 & 3 \\
$3 \mathrm{~min}$ to $<5 \mathrm{~min}$ & 10.0 & 7.5 \\
$5 \mathrm{~min}$ to $<7 \mathrm{~min}$ & 15.0 & 12.5 \\
$7 \mathrm{~min}$ to $>10 \mathrm{~min}$ & 12.5 & 15 \\
\hline \multicolumn{2}{c}{}
\end{tabular}

Table 5 present the proportions of total pedestrian, women, and men and how confidence intervals compare between women and men to identify the space uses. If democratic streets attract more people and women, people count will yield a supportive street main effect. The results also count for males, although this research did not hypothesise whether men favour the use of more pedestrian streets. The study applied the standard error because interested in the variability of sample means, and the mean is always in the centre of the confidence interval. $95 \%$ confidence intervals contain the actual means. If the interval is small, the sample mean must be very close to the true mean. Conversely, if the confidence interval is extensive, then the sample mean could be very different from the true mean, indicating that it is an inadequate representation of the population.

The result shows that women pedestrians made up proportion 0.35 of weekday users (SE $0.01,95 \% \mathrm{Cl}[0.39,0.45])$ and 0.38 of weekend users (SE $0.02,95 \% \mathrm{Cl}[0.55,0.63]$ ) in Kasturi Walk. Compare to the men pedestrian which score highest mean 0.46 of weekday users (SE $0.02,95 \% \mathrm{Cl}[0.25,0.29]$ ) and 0.57 of weekend users (SE $0.02,95 \% \mathrm{Cl}[0.45,0.53])$. To be observed, the proportion of women pedestrians slightly similar between weekday and weekend, but the proportion of men was largely the difference between weekday and weekend in Kasturi Walk. It can be said that men avoid being in public space during the weekend compare to women which play a role as a head of household, other than full-time workers.

The differences in proportions of women and men in Petaling Street as weekday and weekend users differed significantly. On weekday, the mean score for women pedestrian is 0.40 (SE $0.01,95 \% \mathrm{Cl}[0.70,0.83]$ ) compare to 0.44 (SE $0.02,95 \% \mathrm{Cl}[0.77,0.85]$ ) on weekdays. While men pedestrian recorded the mean score 0.51 (SE $0.02,95 \% \mathrm{Cl}[0.66,0.72]$ ) and increased to 0.66 (SE $0.02,95 \%$ $\mathrm{Cl}[0.71,0.82])$ on weekend. Overall, the differences in proportions of women and males were largely significant in Petaling Street. It was clear that men use public space very differently than women. This finding also indicates that moving around in urban public spaces is a common experience for women and men where different gender carry different roles in socio-economic and household responsibility.

Table 5. Estimates of the proportion of total pedestrian, women and men by the streets

\begin{tabular}{|l|c|c|c|c|c|c|}
\hline \multirow{2}{*}{} & \multicolumn{3}{|c|}{ Weekday } & \multicolumn{3}{c|}{ Weekend } \\
\cline { 2 - 7 } & Mean & SE & $95 \% \mathrm{Cl}$ & Mean & SE & $95 \% \mathrm{Cl}$ \\
\hline - Kasturi Walk & & & & & & \\
- Petaling Street & 0.18 & 0.02 & $0.24,0.38$ & 0.31 & 0.02 & $0.69,0.57$ \\
\hline Total women pedestrian & 0.27 & 0.02 & $0.77,0.62$ & 0.36 & 0.01 & $0.57,0.62$ \\
- Kasturi Walk & & & & & & \\
- Petaling Street & 0.35 & 0.01 & $0.39,0.45$ & 0.38 & 0.02 & $0.55,0.63$ \\
& 0.40 & 0.01 & $0.70,0.83$ & 0.44 & 0.02 & $0.77,0.85$ \\
\hline Total men pedestrian & & & & & & \\
- Kasturi Walk & & & & & & \\
- Petaling Street & 0.46 & 0.02 & $0.25,0.29$ & 0.57 & 0.02 & $0.45,0.53$ \\
\hline
\end{tabular}

\subsection{Discussion}

In this research, the integrated street draws more people and enhance walkability. However, in contrast to the results of the integration value of Kasturi Walk, the less integrated street encourages fewer people present in a shorter duration of stay. More integrated streets, Petaling Street, as an example, are more accessible from other streets likely to attract more women pedestrians. In this sense, Space Syntax is useful to provide a better understanding of the role of the street network in supporting public life because it deals with both spatial and functional aspects of street space. However, many other factors contribute to the lack of absence of pedestrian in the streets. The factors contributed may the land use pattern, pathway and street infrastructures, public transportation system, urban design and built environment qualities, and types of activities include economic and social activity.

The results of the proportion between women and men in uses of public spaces show that many factors influence the presence of women; a variety of goods and services, a group of users, accessibility and walkability, and convenient. However, women pedestrianonly being in the streets in a short time and rush. The observation results found that only women tourists walk leisurely. The different group of women pedestrians carry different objectives of being in the streets. To compare the range of activities and goods in both streets, Petaling Street is the preferable place to be visited by women. When the street offers a variety of goods, it will consequently 
encourage social engagement and social exchange. The pattern of activities taking place in the streets justifies that people intuitively re-configures the space for their best uses.
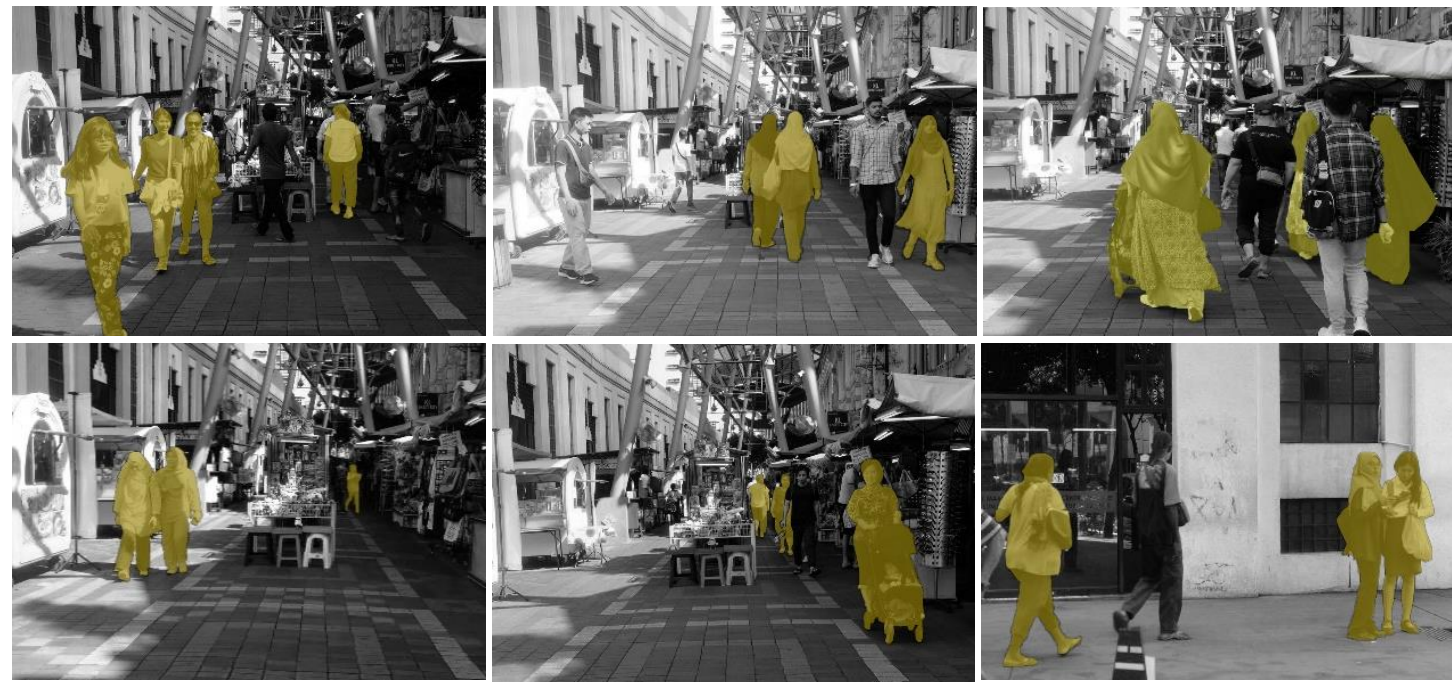

Fig. 7: Women are always seen in public space during daytime when they have a purpose - going to work, market to buy groceries and other such activities.
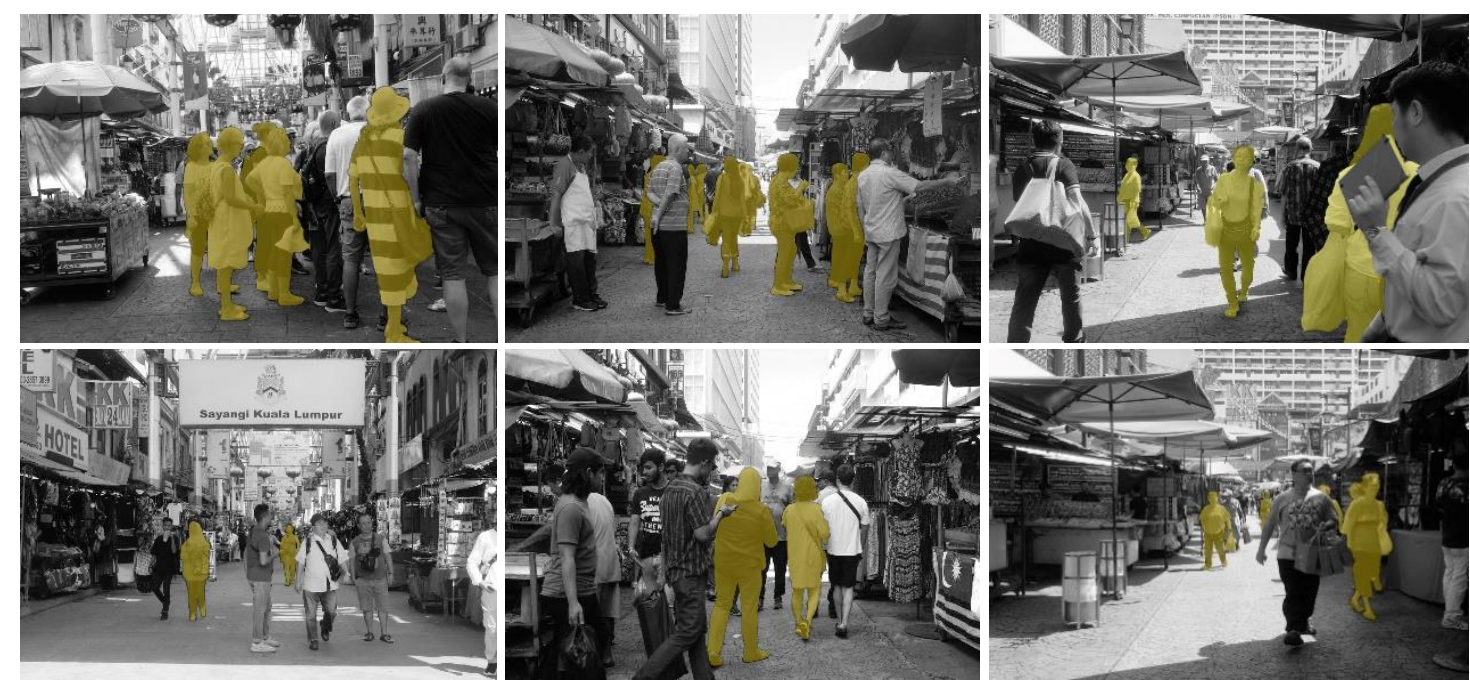

Fig. 8: There is an intense and democratic use of the space in Petaling Street by women and men of different age, race and nationality, and a diversity of activities taking place there.

This research has no attempt to evaluate to what extent women pedestrians feel safe in the aspect of crime and built environment or urban design. This research only reveals the everyday activities and movement and how women pedestrians were feeling of safety when in crowded places, surrounded by men and foreign workers. The feeling of safety in the crowded and congested streets may influence by the presence of many people, patrolling by the police, segregated lane between pedestrian paths and road, and the smallscale commercial activity along the streets. Women's experience of safety in urban areas is different compared to men, especially when the area dominance by men. Besides, the level of fear among women pedestrians is varied by location, time of day, mode of transport, and the setting of other uses.

Returning to the question of the democratic street - spatial justice among women pedestrian, the research findings are manifold women pedestrians dominant the streets. However, statistically, the number of men pedestrians is higher than women pedestrians. Indeed, the pedestrian volume challenging to compare with the activities happening in the less integrated streets like Kasturi Walk. The research thus suggests the further research to understand the street network patterns; the structured observation that carried in this 
research could not answer the vital question about how democratic and equitable the streets are, of who might benefit most, who "own" space, or who will avoid the street and why.

\subsection{Conclusion \& Recommendations}

Streets are paved surfaces that exist in physical spaces within a city. The spaces in between the streets and the streets themselves provide places for people to live, work, worship, socialise and engage in countless other urban activities that constitute public life. Recall that, and we should refocus our attention to people and places rather than land users to become truly democratic and equitable - after all, it is people that make places. Yet, in conclusion, a successful public space is one where users of different backgrounds can coexist without one group dominating another.

The findings show that the application of Space Syntax in examining the spatial configuration of the street networks in a city makes it as a baseline study. This is true in a city where public life has been squeezed into nonexistence, as well as in the city that has an abundance of pedestrian life, but a depressed economy and infrastructures that prevents establishing the underlying condition for a decent walking environment for everyone. Moreover, the findings contribute to providing better insights on spatial design interventions and spatial design normative policymaking to help urban designers, architects, urban managers and the local governments. They are the common aspects for them to understand how urban space work the way they do as well as to deliver the social, economic and environmental expectations of the pedestrian particularly.

\section{Acknowledgements}

The author gratefully acknowledges the support of Universiti Teknologi MARA and Institute of Research Centre under the Lestari grant 600-IRMI 5/3/Lestari (040-2018).

\section{References}

Arjmand, R. (2016). Public Urban Space, Gender and Segregation: Women-Only Urban Parks in Iran. Routledge.

Beebeejaun, Y. (2017). Gender, Urban Space, and the Right to Everyday Life. Journal of Urban Affairs, 39(3), 323-334.

Cheshmehzangi, A., and Heat, T. (2012). Urban Identities: Influences on Socio-Environmental Values and Spatial Inter-Relations. Procedia-Social and Behavioral Sciences, 36, 253-264.

Francis, M. (2016). The Making of Democratic Streets. Contesti. Città, Territori, Progetti, (1-2), 192-213.

Gehl, J., and Svarre, B. (2013). How to Study Public Life. Island Press.

Goodsell, C. T. (2003). The Concept of Public Space and Its Democratic Manifestations. American Review of Public Administration, 33(4), 361-83.

Hajrasouliha, A., and Yin, L. (2015). The Impact of Street Network Connectivity on Pedestrian Volume. Urban Studies, 52(13), 2483-2497.

Hillier, B., and Hanson, J. (1989). The Social Logic of Space. Cambridge University Press.

Hillier, B. (2007). Space Is The Machine: A Configurational Theory of Architecture. Space Syntax.

Hillier, B., Penn, A., Hanson, J., Grajewski, T., and Xu, J. (1993). Natural Movement: or, Configuration and Attraction in Urban Pedestrian Movement. Environment and Planning B: Planning and Design, 20(1), 29-66.

Khalili, A., Fallah, S. N., bin Mohamad Rasdi, M. T., Farzin, A. A., and Mansouri, S. A. (2015). Conduciveness of Women Social Setting in Traditional Iranian Bazaar from Functional Dimension. Asian Social Science, 11(12), 297.

Mehta, V. (2007). Lively Streets: Determining Environmental Characteristics to Support Social Behavior. Journal of Planning Education and Research, 27(2), $165-187$.

Mehta, V. (2009). Look closely and You Will See, Listen Carefully and You Will Hear: Urban design and Social Interaction on Streets. Journal of Urban Design, 14(1), 2964.

Mehta, V., and Bosson, J. K. (2010). Third Places and the Social Life of Streets. Environment and Behavior, 42(6), 779-805.

Mehta, V. (2013). The Street: A Quintessential Social Public Space. Routledge.

Rudofsky, B. (1969). Streets for People: A Primer for Americans. Garden City, NY: Doubleday.

Souza, A. C. S., Bittencourt, L., and Taco, P. W. G. (2018). Women's Perspective in Pedestrian Mobility Planning: The Case of Brasilia. Transportation Research Procedia, $33,131-138$.

Tandogan, O., and Ilhan, B. S. (2016). Fear of Crime In Public Spaces: From The View of Women Living In Cities. Procedia Engineering, 161, 2011-2018.

Villani, C. and Talamini, G. (2016). Patterns of Stationary Activities in the Elevated Pedestrian Networks of High-Density Asian Cities: The Case of Mong Kok, Hong Kong. $8^{\text {th }}$ Asian Conference on Environment-Behaviour Studies (AcE-Bs2019), Vol. 4, 12(321-328). Environment-Behaviour Proceedings Journal, Langkawi, Malaysia. 
Khalid, N. S., et.al./ $8^{\text {th }}$ AicQoL2020Malacca, Mahkota Hotel Melaka, Malacca, Malaysia, 18-19 Mar 2020 /E-BPJ, 5(13), Mar 2020 (pp.405-415)

Zavestoski, S., and Agyeman, J. (Eds.). (2014). Incomplete Streets: Processes, Practices, and Possibilities. Routledge. 